\title{
Designing Interactive Learning Media for Singing Traditional Songs in Elementary School
}

\author{
Uni Tawangsasi*, Yudi Sukmayadi \\ Universitas Pendidikan Indonesia \\ Bandung, Indonesia \\ *uni.tawangsasi13@gmail.com,yudi.sukmayadi@upi.edu
}

\begin{abstract}
The preservation of Indonesian traditional culture can be done in various ways. In the field of music education, this can be done, among others, by guiding students to sing various traditional songs in Indonesia. However, after making observations in several primary and high schools, the researchers found that students still have limited knowledge regarding traditional songs in Indonesia. This article describes the design of instructional media in the form of interactive video "Let's Sing Together" for 3rd grade elementary school students in order to increase students' knowledge of traditional songs and guide them to be able to sing the traditional songs. The main purpose of this learning media design is to produce learning media that can make it easier for students to learn traditional songs, both in class, extracurricular activities, and at home with parental guidance. This research is a development research that is oriented to the development of learning multimedia products. The stages in this research broadly include the preliminary study stage, the planning stage, the design stage, and the development stage. The process of designing this instructional media includes preliminary studies, script making stage, and product making stage. The final product is an interactive learning $\mathrm{CD}$, consists of an opening videos, basic singing technique material and a collection of videos of traditional songs using simple, and fun choreography, and closing.
\end{abstract}

Keywords-interactive media, singing, traditional songs

\section{INTRODUCTION}

Indonesia has a diverse ethnicities and cultures. Indonesian people need to preserve their cultural diversity because it is a valuable asset. One of the cultural elements that needs to be preserved is the traditional arts [1]. The preservation of traditional arts in Indonesia can be carried out in various ways. In the field of education, such as to guiding students to know and love the traditional arts. In the field of music education, the first step to introduce various traditional arts is to guide students in knowing various Indonesian traditional songs. This is because the traditional song is one of the simple art forms and can be easily learned by students, both at the elementary, intermediate, and upper levels [2].

The problem that the researchers found when making observations in 4 schools was SDN Cidadap 2 Bandung, SDN Sindangsono 4, SMA Pasundan 2 Cimahi, and SMK PGRI 1
Cimahi showed the students in these schools have limited knowledge about the Indonesian traditional songs. Only a few songs were recognized by students, for example: Manuk Dadali, Mojang Priangan, Panon Hideung, and Mawar Bodas. All the mentioned songs originated from West Java. This can be caused by a lack of traditional songs learning in schools, having traditional art teachers who are not from the specific field of art or musical art who have limited knowledge of traditional songs, and there is no learning media that supports learning to sing traditional songs in schools. In addition, this can also be caused by the ineffective method of learning and training traditional songs, both in class and in extracurricular activities. Related to this, one solution that can be given namely by creating customized learning media suited to the habits and skills of students, in order to make the learning process more fun and effective for the students.

Most of the students in the 21st century have expertise digital literacy (new media literacy) and ICT because of the influence of the developing technology $[3,4]$. Students in the 21 st century are already accustomed to digital media in their daily activities from an early age, starting from playing, learning, and many any other relevant activities. Because of that situation, we need a learning media that uses digital media that is packaged attractively in order to stimulate students' interest in knowing and learning Indonesian traditional songs. Therefore, the use of teaching materials such as the Collection of Traditional Songs book that shows the material in the form of scores is no longer effective in motivating students to learn traditional songs. In addition, the use of the imitation method, which in the process of asking students to sing songs sung by the teacher, has become a monotonous method [5].

Based on that, the author gives a solution of the problem, namely designing a learning media in the form of interactive video entitled "Let's Sing Together" for students of 3rd grade. The purpose of this media design aims to produce instructional media product that can ease the elementary-level students to recognize and be able to sing Indonesian traditional songs. This is also expected to be a stimulus for students to love traditional songs, in the long run it will have a positive impact on the preservation of the Indonesian traditional culture. 


\section{THEORETICAL REVIEW}

\section{A. Interactive Media}

Multimedia is a media that combines two or more media elements (text, graphics, images, photos, audio, video and animation) in an integrated manner [6,7]. Interactive multimedia is a learning program consisting of various learning resources using computer operations [8]. The program is deliberately designed and assesses whether the feasibility of the responses (e.g. menu, problem, simulation, question) affect the program's sequence, size, context and form. The characteristic of learning multimedia is that it has more than one convergent media, for example, combining audio and visual elements; interactive, in the sense that it has the ability to accommodate users' responses; and is independent, in the sense of providing convenience and completeness of content in such a way that users can use it without the guidance of others [8].

Interactive learning media can increase students' interest and motivation, focus the students' attention, allow students to learn independently, make students active in the learning process, and create a pleasant learning atmosphere so learning activity can be conducted effectively, efficiently, and attractively to help students achieve basic competences that have been set $[9,10]$.

\section{B. Singing}

Singing activity is one of the activities favored by children. Almost every child enjoy the songs or songs that were sung that they listen to, especially if the songs are sung by children of their age and followed by simple body movements using learning aids. Singing is an integral part of the world of children $[11,12]$. This is not surprising, because the song is basically a form of tonal language, namely the shape and pitch of the voice. Meanwhile, tonal language will actually bring them a cheerful, serene, sad and uplifting atmosphere.

\section{Traditional Songs}

Traditional songs are songs or music that were originated from a certain area and became popular because they were sung by both the people of that area and other people outside of the said area. This form of the song is very simple and uses the traditional language. Many traditional songs have the theme of everyday life so they are easy to understand and easily accepted in various traditional activities. In general, the composer of this traditional song is no longer known (NN) $[13,14]$.

\section{METHODS}

This research is a development research that is oriented to the development of learning multimedia products. The stages in this research broadly include the preliminary study stage, the planning stage, the design stage, and the development stage. The preliminary study stage, namely as a needs analysis of problems that arise in the process of learning regional songs. Starting from this problem then found a solution that can solve problems related to learning. Next, the planning stage, which is the stage of making lesson design plans in developing more effective regional song learning. Furthermore, the design and development stage, namely the workflow is more focused on organizing activities, compiling content and making learning media products.

The location of the research conducted by researchers was SDN Cidadap 2 Bandung, SDN Sindangsono 4, SMK PGRI 1 Cimahi, and SMA Pasundan 2 Bandung. Researchers conducted research at primary and secondary schools in order to better know and be able to compare students' knowledge of regional songs at each student level. The data were obtained through interviews with grade 1 to 6 teachers at the primary school level and cultural arts teachers at the secondary school level. Interviews were also conducted with students. At the primary school level, the researcher interviewed 10 students in grades 3, 4, 5, 6. Ten student in each grade. The researcher only interviewed students starting from grade 3 because grade 1 and grade 2 students found it difficult to provide information during interview. In high school, the researcher interviewed 15 grade 1 students, 15 grade 2 students, and 15 grade 3 students. In addition, the researcher also conducted observations in each of these schools to find out the problems of learning regional songs. The instruments used to collect data in this study were interview and observation guidelines. The main questions asked of respondents include:

- Do you like Indonesian traditional songs?

- What traditional songs do you know?

- What is the reason you like / dislike learning traditional songs?

\section{RESULTS AND DISCUSSION}

The learning media for singing traditional songs for 3rd grade elementary school students has been designed and made based on a needs analysis, and then concluded after researcher obtained various information, including the ineffective learning of traditional songs due to a lack of motivation and students' interests in learning to sing traditional songs, therefore it requires interactive multimedia learning. Information gathering was done through field studies. Field studies were carried out by making observations at SDN. Cidadap 2 Bandung and SDN Sindangsono 4 in Tangerang Regency. As a complement, the writer also made observations at SMK PGRI 1 Cimahi and SMA Pasundan 2 Cimahi to compare the results of basic and upper level students' knowledge about traditional songs. In addition, the authors conducted a needs analysis interview with classroom teachers and cultural arts teachers with the aim of obtaining information related to the learning process of traditional songs and developing multimedia learning needed by students.

Based on the results of interviews and observations, the following data were obtained; Elementary school students only 
master traditional songs from West Java which they often heard. This happened because the learning process for singing traditional songs was less effective, which is indicated by students who were bored, disinterested, and were noisy in the classroom during the teaching and learning activities. The classroom teacher used simple media in the form of song scores displayed in front of the class and sang it in front of the students, then students were asked to sing the song according to the example given by the teacher. Students were also less enthusiastic about singing the song they heard for the first time. In other elementary schools, the activity of learning to sing traditional songs was less effective, because classroom teachers were only had limited knowledge about Indonesian traditional songs, making it difficult to made example about the matter in front of students. In addition, students were less enthusiastic in participating in the learning process of singing traditional songs carried out by teachers in these schools because the learning strategies applied tend to use traditional or expository approaches, teacher centered learning, teachers never used interactive multimedia learning. This caused students to have difficulty mastering singing skills and getting to know various kinds of Indonesian traditional songs. Therefore, the interactive media "Let's Sing Together" is needed by students. The use of interactive media as a learning resource other than traditional song collection books can have a good impact on the learning process and outcomes.

This interactive media is in the form of videos recorded using the Android Samsung A30S and edited using a video editor application created by NexStreaming, namely KineMaster. The target users of this interactive media product are students in 3rd grade of elementary school. This learning multimedia product is packaged in an interactive Compact Disc (CD) that can be run on a computer. The interactive media production process is processed in the KineMaster and PixelLab applications as supporting applications. KineMaster is a video editor application on an Android smartphone that has an easy-to-use appearance and features like an editor on a computer, so the video editing process was not complicated. The production process can run smoothly, quickly, and be more organized because it is based on a pre-made video design and the readiness of the required materials according to users' characteristics. The process of making interactive learning videos is divided into 2 main activities, namely the script making and product making. In script making, the first thing the writer did was to design a learning video, prepare basic vocal material, create a script as a guide in delivering the material, choose traditional songs, make choreography and choose dancers. Meanwhile, product making includes create the watermark, video recording, editing processes and rendering.

\section{A. Script Making Process of the Video}

The process of making a video script began with designing an interactive learning video. The author made a video design which includes an opening performance, basic vocal material for elementary school students, a video display of traditional songs accompanied by choreography, and a closing.
The first thing the writer did after designing the video was to prepare basic vocal material. The said basic vocal material only includes body posture, articulations, breathing techniques, and expressions. This is because this video was made for elementary students, so that vocal material was adapted to the understanding and abilities of elementary school students [11]. Furthermore, the author prepared a script to convey basic vocal material interactively during video recording. One example of the process of delivering material that is carried out interactively is in the dialogue "to do the correct articulation technique, let's sing the Rainbow song together with me, just like what we did just now, friends". The script is prepared by the writer with a friendly attention and time effectiveness, which aims to make the material delivery process not boring and interesting to be noticed by the target audience.

The next step is the selection of traditional songs. The writer chose five traditional songs from different provinces The songs were Kampuang Nan Jauah di Mato (West Sumatra), Si Patokaan (North Sulawesi), Cik-cik Periuk (West Kalimantan), Ayo Mama (Maluku), and Tokecang (West Java). Apart from considering the origin of the song, the songs were chosen musically based on the tempo, lyrics and melody. The tempo of the traditional songs chosen by the researchers are relatively fast. This is because in this interactive learning video the researcher wanted to stimulate students to be interested in learning Indonesian traditional songs. So, choosing a song with a fast tempo will create an impression of enthusiasm so as to stimulate the enthusiasm of students in learning it. In addition, the selection of songs with fast tempo also supported the choreography function which aimed to increase students' activities and interests. Next, the researchers chose the song based on its simple lyrics. The lyrics in those traditional songs only consist of 4 - 5 verses but contain a lot of repetition that make them easily remembered by students. The last thing the writer considered in choosing the songs were the melody aspect. The melodies in these songs tend to have 'stepping' intervals, not 'jumping' intervals so that they would be easily sung by students.

Next is making choreography. The reason the researcher made a video of learning to sing traditional songs using simple choreography was to increase the activeness, interests, and enthusiasms of students in learning the traditional songs. This is because the aspect of movement that is entertaining in children's learning makes children more interested and excited in learning. Besides that, it can also develop students' activeness, creativity, and memory [11]. The choreography is done by the researcher with the help of someone who is experienced in making choreography for choir competitions and such. The choreography was different for each song, adjusted to the rhythm of the song. The choreography basically coordinates the movements of the head, shoulders, hands, waist and legs which are were done in turn to the right and left one at a time but were developed in each song. The choreography in each song contains 3-4 concept movements that were repeated.

The final step in making a video script is the selection of dancers. The researcher chose three ten-year-old elementary 
school students as dancers in this interactive learning video. The researcher determined the age of the dancers to be at the same level as the target video audience. The target of this learning video was 3rd grade elementary school students, so dancers with ages that are not much different from 3 rd grade elementary school students make students more interested in following the movement.

\section{B. Product Making}

The first thing the researcher did was to create a watermark as well as the main $\log$ o of this video for the opening and closing of the video. In making this watermark, researchers used the PixelLab application. The images contained in the watermark are a map of Indonesia, a symbol of musical notation, and two children wearing elementary school uniforms. The entire image is downloaded via Google and edited into a .png file, then put together in a circle and title. The watermark show in figure 1.

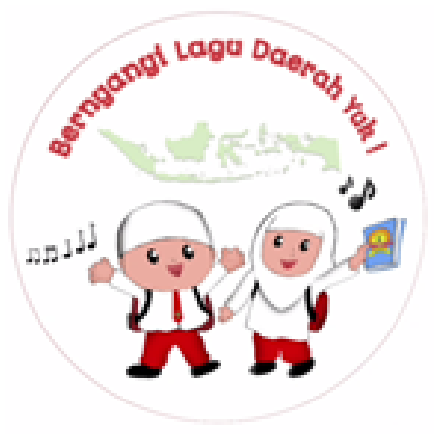

Fig. 1. The watermark.

After that, the author made an opening video. These frames consist of images, animation, and audio. The images in this frame are downloaded via Google while the animation is made by the author using the PixelLab and KineMaster applications. The process of editing the entire frame was done using the KineMaster application on Android. The next frame was the researcher's opening. The opening included greeting, asking the students' well-being, and introductions. Researcher's opening video and Introductions in figure 2.

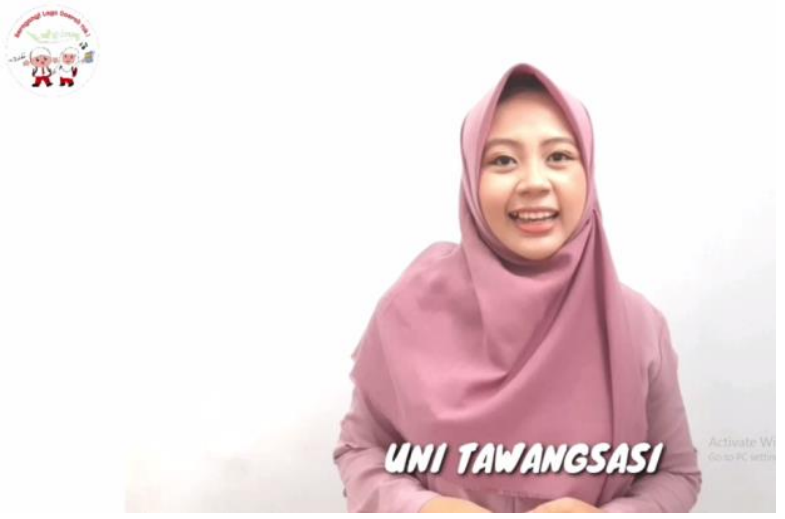

Fig. 2. Researcher's opening video and introductions.
Then, there was the delivery of basic vocal material as well as an example of an interactive singing technique tutorial. This video recording process used the Android Samsung Galaxy A30S. The recording process was then edited by the author using an explanatory explanation in the form of text or images on the required video section. In addition, a video consisting of correct and incorrect examples is given, with the aim of making students better understand the material presented. The entire process of delivering the material and examples lasted for 5 minutes. Correct and incorrect examples in figure 3.

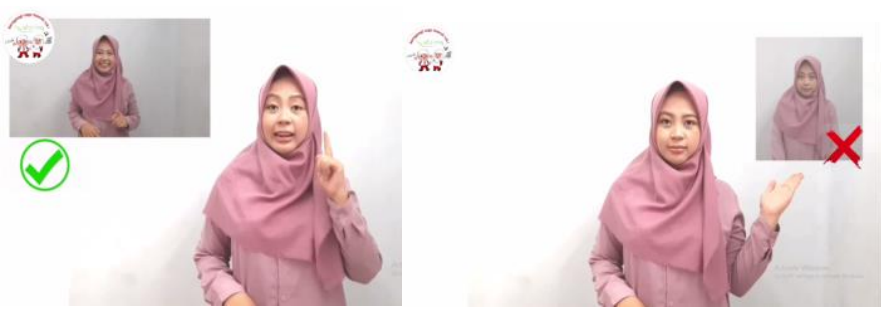

Fig. 3. Correct and incorrect examples.

The next process is recording choreography with the dancers. The dance recording process was carried out after prior training for the dancers to master the choreography of each traditional song. The recording process was carried out in a closed room. After the recording process, the author edited the entire dance video using the KineMaster application. The researcher brought together dance videos and traditional song audio, and added running texts to caption the song lyrics underneath the dance videos. The entire section was 15 minutes long. The choreography is accompanied by audio and lyrics under the video show in figure 4.

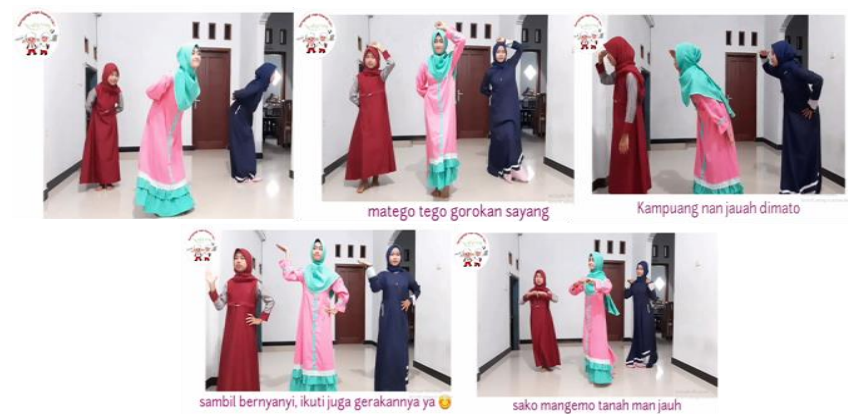

Fig. 4. The choreography is accompanied by audio and lyrics under the video.

The last process of making the product was making the closing part of the video. The closing part of the video was filled with speakers who invited students to learn Indonesian traditional songs, because Indonesian traditional songs are very fun to sing and make students get to know the various ethnic groups and cultures in Indonesia. Then the speaker closed the video.

After the overall editing process, the researcher had to check again. The checking was carried out internally by the author and then completed and converted into a smaller size than the original. This paper only discusses the process of 
making interactive learning videos Bernyanyi Lagu Daerah Yuk carried out by the researchers. The next process, such as evaluation and testing of the target audience, will be carried out at a later date after the video design has been completed.

\section{CONCLUSION}

This interactive learning media is made based on problems that occur in many schools, namely students who have limited knowledge of Indonesian traditional songs. The design of the video was carried out through two main activities, namely making a video script and making a product. The making of a video script consists of the process of making a learning video design, determining basic vocal materials, making interactive dialogues to deliver the materials, selecting traditional songs, making choreography and selecting dancers. Meanwhile, product making includes video recording and editing processes. This interactive learning video produces a product in the form of an interactive learning $\mathrm{CD}$ with a duration of 15 minutes consists of an introduction, basic vocal materials, five traditional songs presented using choreography, audio, and running lyrics text, and a closing part.

This interactive learning media is expected to be evaluated by experts so that it may become suggestions and input for writers to make improvements and development, so it can be used by educators as a medium in learning traditional songs for students, both in class and extracurricular activities. In addition, it can be used by students self-taught and guided by parents to make it easier to achieve goals and mastery of traditional songs. This learning media is also expected to be a stimulus for students to be interested in learning and singing Indonesian traditional songs.

This product is still limited to a simple tutorial program and a collection of traditional songs. Further product development on interactive learning CDs can be done by developing learning software with other programs, for example simulation, drill \& practice, authoware.

\section{REFERENCES}

[1] Darsiharjo, Caturwati E, Rustiyanti S, and Sumiati L. Pengembangan Potensi Seni Tradisi di Jawa Barat melalui Pembinaan Sentra-sentra Budaya. 2009

[2] P. Sularso, "Upaya Pelestarian Kearifan Lokal melalui Ekstrakurikuler Karawitan di SMP Negeri 1 Jiwan," Jurnal Pancasila dan Kewarganegaraan, vol. 5, no. 1, 2017.

[3] A. Sujana and D. Rachmatin, "Literasi digital abad 21 bagi mahasiswa PGSD: apa, mengapa, dan bagaimana," In Current Research in Education: Conference Series Journal, vol. 1, no. 1, p. 003, 2019.

[4] N. Pratiwi and N. Pritanova, "Pengaruh Literasi Digital terhadap Psikologis Anak dan Remaja," Jurnal Ilmiah Program Studi Pendidikan Bahasa dan Sastra Indonesia, vol. 6, no. 1, pp. 11-24, 2017.

[5] A.G. Jafloenty, "Inovasi Pembelajaran Bernyanyi Unisono Dengan Metode Solatmingkom Di Smp Nasima Semarang," JURNAL SENI MUSIK, vol. 8, no. 2, pp. 89-94, 2019.

[6] P.P. Rusdewanti and A. Gafur, "Pengembangan media pembelajaran interaktif seni musik untuk siswa SMP," Jurnal Inovasi Teknologi Pendidikan, vol. 1, no. 2, pp. 153-164, 2014.

[7] R.C. Clark and R.E. Mayer, E-Learning and the Science of Instruction ; Proven Guidelines for Consumers and Designers of Multimedia Learning. Canada: John Wiley and Sons, 2016.

[8] R.A. Schweir and E. Misanchuk, Interactive Multimedia Instructional. New Jersey: Englewood Cliffs, 1993.

[9] Ariasdi, Panduan Pengembangan Multimedia Pembelajaran. Jurnal Inovasi Teknologi Pendidikan, 2015.

[10] J. Radich, "Technology and interactive media as tools in early childhood programs serving children from birth through age 8," Every Child, vol. 19, no. 4, pp. 18, 2013.

[11] F. Diana, "Penerapan Metode Bernyanyi dengan Menggunakan Alat Bantu Pembelajaran,” Jurnal Inovasi Teknologi Pendidikan, 2013.

[12] F.S.S. Sinaga, E. Maestro, E. Winangsit and Y. Yensharti, "Learning and Singing: Thematic Children Songs in Kindergarten," Advances in Social Science, Education and Humanities Research, 2019.

[13] U.I. Arsyah and A. Munandar, "Perancangan Media Pembelajaran Lagulagu Daerah Pada Yayasan Pendidikan Al Mawaddah Teladan Kisaran Berbasis Multimedia," Jurnal Manajemen Informatika dan Teknik Komputer, vol. 2, no. 2, pp. 127-132, 2017.

[14] S.H. Motherway, The Globalization of Irish Traditional Song Performance. New York: Ashgate Publishing, 2013. 